Центр воєнно-стратегічних досліджень Національного університету оборони України імені Івана Черняхівського, Київ

\title{
Топогеодезичне забезпечення як складова інформаційного забезпечення сил оборони України
}

Резюме. У статті проведено аналіз стану топогеодезичного забезпечення сил оборони України, зокрема Збройних Сил України. За результатами аналізу запропоновано підходи до подальшого вдосконалення топогеодезичного забезпечення як складової інформаційного забезпечення сил оборони України на основі впровадження геоінформаційних систем.

Ключові слова: топогеодезичне забезпечення, геоінформаційна система.

Постановка проблеми. Проведення Антитерористичної операції (АТО), операції Об'єднаних Сил (ООС) на Сході України висвітлили серйозні прогалини у сфері інформаційного забезпечення Збройних Сил (3С) України та інших складових сил оборони, зокрема забезпечення геопросторовими даними.

Висока динаміка сучасних операцій (бойових дій), розвиток високоточних ударних комплексів i систем, впровадження автоматизованих систем управління, необхідність швидкого реагування на зміни обстановки, підвищення вимог до оперативності, точності та надійності топогеодезичної інформації для якісного планування та ефективнішого застосування сил оборони, визначають необхідність удосконалення системи топогеодезичного забезпечення як складової інформаційного забезпечення сил оборони України.

Аналіз останніх досліджень і публікацій 3 питань удосконалення топогеодезичного забезпечення ЗС України свідчить про те, що сучасні принципи організації топогеодезичного забезпечення у ЗС України впроваджуються недостатньо ефективно 3 таких причин [1]:

тривалий час не виконуються загальнодержавні роботи 3 топографічного картографування. Досвід проведення АТО, OOC на території Донецької та Луганської областей ще раз підкреслив необхідність завчасної підготовки території держави у топогеодезичному відношенні. Саме територіям східної України за роки незалежності приділялось найменше уваги щодо створення та накопичення запасів топографічних карт, оновлення їх змісту;

топографічне картографування в Україні здійснюється фактично на основі радянських нормативно-технічних документів, які перекладені українською мовою та містять лише незначні зміни, а тому морально застаріли;

недостатне використання можливостей обчислювальної техніки і машинної графіки в процесах створення i масової обробки картографічної інформації.

Критичний стан топографічної вивченості території України неодноразово висвітлювався в наукових і науково-технічних публікаціях $[2,3]$. Проте дослідження з питань топогеодезичного та картографічного забезпечення в сучасних умовах складових сил оборони держави не проводились [4].

Зважаючи на [5], топогеодезичне забезпечення як невід'ємна складова інформаційного забезпечення ЗС України та інших складових сил оборони потребує подальшого удосконалення для якісного виконання комплексу топографо-геодезичних i картографічних робіт та своєчасного задоволення їх геопросторовими даними.

Метою статті є обгрунтування підходів до визначення пріоритетних напрямів розвитку на довгострокову перспективу системи топогеодезичного забезпечення як складової інформаційного забезпечення військ (сил) Збройних Сил та інших складових сил оборони на основі результатів аналізу досвіду проведення АТО, ООС на Сході України.

Виклад основного матеріалу. Аналіз ведення бойових дій у війнах, конфліктах переконливо свідчить, що 3 усіх видів оперативного забезпечення топогеодезичне забезпечення $є$ одним 3 надважливих, без якого неможливо ефективно здійснювати інші види забезпечення. $\mathrm{y}$ збройних силах провідних країн світу топогеодезичне забезпечення розглядається як один 3 основних видів забезпечення військ, який має на меті забезпечення органів військового управління, військ (сил) топографічними, 
спеціальними, цифровими та електронними картами, фотодокументами про місцевість, астрономо-геодезичними і гравіметричними даними, які потрібні для планування і ведення бойових дій [1].

Досвід ведення бойових дій на Сході України показав, що ефективність застосування систем управління військами та зброєю ЗС України знаходиться в прямій залежності від інформаційного забезпечення, зокрема від якості топогеодезичного забезпечення, забезпечення органів військового управління, військ (сил) геопросторовими даними про місцевість. Не буде перебільшенням сказати, що без якісних i актуальних геопросторових даних для потреб 3С України та інших складових сил оборони не можливо гарантовано забезпечити адекватне і гнучке реагування на весь спектр загроз національній безпеці України [5].

Інформачійне забезпечення (у військовій сфері) - сукупність заходів органів військового управління усіх рівнів, дій військ (сил) та інших суб'єктів інформаційної діяльності для створення (формування) i використання в інформаційному просторі необхідних інформаційних ресурсів для реалізації процесів управління в інтересах оборони держави [6].

Загалом, під топогеодезичним (геоінформачійним) забезпеченням ЗС України, як одним із видів оперативного (бойового) забезпечення військ (сил), слід розуміти комплекс заходів із підготовки та доведення до органів військового управління всіх рівнів та військ топогеодезичних i картографічних даних, топографічних i спеціальних (тематичних) карт (зокрема електронних), фотодокументів місцевості, а також астрономо-геодезичних, гравіметричних та інших геопросторових даних для управління військами (силами) та зброєю під час виконання ними поставлених задач.

Основні вимоги, які висуваються до топогеодезичної інформації це достовірність, точність та оперативність.

Як складова інформаційного забезпечення топогеодезичне забезпечення має давати змогу:

вивчення та оцінювання місцевості, орієнтування на ній з визначеною точністю; виконання вимірювань, розрахунків; побудови розрахункових моделей ситуацій i процесів, які відбуваються на місцевості.
3 цією метою топогеодезичні, картографічні та інші геопросторові дані мають включати та забезпечувати:

наявність цифрових карт місцевості на всю визначену територію як у відкритих поширених форматах, так і у вигляді закритих даних;

високу точність зображення об'єктів;

можливість швидкого внесення змін та доповнень.

Сучасні вимоги до топогеодезичного забезпечення обумовлені такими факторами [4]:

1. Стрімкий розвиток інформаційних технологій забезпечив оснащення ЗС України високоточними зразками озброєнь, що призвело до зміни характеру бойових дій 3 переходом до фактично безконтактної війни 3 противником. Новітнє озброєння та військова техніка (ОВТ), застосування сучасних систем всебічного забезпечення військ (сил), розроблення та впровадження нових технічних засобів інформаційного забезпечення потребують на сьогодні додаткових геопросторових даних. Нові виклики та загрози, пов'язані 3 гібридною війною, потребують уточнення завдань підготовки геопросторових даних в інтересах складових сектору безпеки i оборони 3 індивідуальним врахуванням їх специфічних потреб.

2. Розвиток інформаційних технологій у сфері топогеодезичного та картографічного виробництва призвів до впровадження цифрових методів створення та оновлення картографічних даних. Пріоритетного значення набуло використання матеріалів дистанційного зондування Землі 3 високою роздільною здатністю, впровадження геоінформаційних технологій, технологій i засобів картографічного забезпечення автоматизованих систем навігації та управління військами (силами) [7].

3. Усталені масштабні ряди топографічних карт нині, як показав досвід ведення бойових дій на Сході України, не повною мірою відповідають потребам 3С України. Стали затребуваними великомасштабні топографічні карти масштабів 1:25000 і 1:10 000, топографічні плани малих міст масштабу 1:5 000. Водночас зросли вимоги до актуальності просторової інформації.

4. Необхідність виконання значних обсягів картографічних робіт у процесі оновлення топографічних карт уповільнює процес їх актуалізації. Це спонукає до 
вибіркового оновлення лише окремих найважливіших елементів географічної основи карти, а також до пошуків можливостей більш швидкого створення альтернативних просторових даних (ортофотокарти, ортофотоплани тощо), отримання яких $є$ до того ж суттєво дешевшим. Проте проблемою залишається автоматизація процесу створення топографічних карт, яка базується на використанні сучасних спеціалізованих програмних продуктів, які значною мірою забезпечують автоматизований перехід від карти більшого масштабу до карти меншого масштабу.

5. Нові зразки високотехнологічного озброєння потребують належного забезпечення геопросторовими базами даних, створених у відповідних сумісних форматах на єдиній топографічній основі та за єдиними підходами.

Актуальна проблема якісного топогеодезичного забезпечення сил оборони України потребує глибокого комплексного наукового дослідження 3 метою визначення його ролі та місця в єдиній системі інформаційного забезпечення.

До того ж необхідно враховувати сучасні підходи до картографічного забезпечення держав-членів Європейського Союзу та НАТО, міжнародний досвід створення національних інфраструктур геопросторових даних, тенденції розвитку топографо-геодезичної та картографічної діяльності, участі у миротворчих операціях, конкретні потреби силових структур у топографо-геодезичній i картографічній інформації, зокрема в умовах загрози тероризму та кібератак.

Створення ефективної і якісної системи топогеодезичного забезпечення ЗС України в сучасних умовах $є$ складним, але вкрай необхідним завданням. Для його успішного вирішення необхідно залучення не тільки сил $\mathrm{i}$ засобів ЗС України, але й інших зацікавлених центральних органів виконавчої влади, організацій, наукових установ, підприємств промисловості.

Розвиток сучасного суспільства, як i подальший розвиток сучасних збройних сил провідних держав світу, базується насамперед на впровадженні інформаційних технологій. Найважливішою складовою інформаційних технологій $є$ засоби обробки цифрової інформації.

Одним 3 напрямів подальшого удосконалення топогеодезичне забезпечення як невід'ємної складової інформаційного забезпечення державного управління у військовій сфері для своєчасного та якісного задоволення геопросторовими даними потреб 3С України та інших складових сил оборони $є$ впровадження географічних інформаційних систем (ГІС).

Географічна інформаџійна система - це множина структурних елементів, які перебувають між собою у багатофункціональних відносинах i реалізують досягнення в галузі збору, зберігання, аналізу та розповсюдження просторової інформації про об’єкти земної поверхні, природні та суспільні процеси i явища. Вона призначена для вирішення різноманітних завдань людської діяльності 3 використанням формалізованої географічної інформації різного ступеня деталізації з різних сфер (політичної, економічної, демографічної, оборонної тощо) і представлення результатів у зручній для візуального сприйняття формі [8].

Актуальність i необхідність впровадження ГІС ЗС України, як складової інформаційного забезпечення ЗС України, зумовлена загальним подальшим підвищенням вимог військ (сил) до оперативності, повноти i якості інформаційного забезпечення процесу управління Збройними Силами та невідповідністю сучасного стану забезпечення військ (сил) інформацією про місцевість останнім досягненням в області інформаційних технологій.

Геоінформаційне

забезпечення передбачає циркуляцію даних про місцевість по каналах, які пов'язані з базами даних ГІС. Власне, вони i лежать в основі геоінформаційного забезпечення.

Цифрова картографічна інформація (ЦКІ) становить основу інформації, яка використовується в ГІС та застосовується для координатної прив'язки різноманітних видів інформації, необхідної для планування операцій (бойових дій), застосування зброї.

Цифрова картографічна інформація інформація про місцевість, об'єкти на ній та їхні характеристики, які представлені в цифровій формі. До неї належать цифрові карти, цифрові моделі місцевості, цифрові моделі рельєфу, електронні карти тощо [8].

Як визначено у [8] за своєю суттю ГІС це поєднання географічної або топографічної карти та великого масиву інформації, яка представлена у цифровій формі, систематизована та прив'язана до відповідного точки картографічного зображення. 
ГІС виконує дві найважливіші функції: створення цифрової карти місцевості, яка інтегрована $з$ розширеною базою даних, та перетворення цифрової карти в електронну 3 можливістю інтерактивної роботи 3 нею користувача.

Цифрова карта - модель земної поверхні записана цифрами в кодовій формі і за встановленою структурою на носієві інформації.

Електронна карта - картографічне зображення, створене на основі даних цифрових карт i візуалізоване на відеомоніторі комп'ютера або відеоекрані іншого пристрою (наприклад, супутникового навігатора).

Отже ГІС дає змогу створювати та підтримувати цифрові моделі обстановки (ЦМО) - оперативну, тактичну обстановку у цифровому вигляді для 3С України, інших складових сил оборони.

Цифрова модель обстановки оперативна (тактична) обстановка у цифровому вигляді, яка створена за допомогою спеціальних програмних засобів i візуалізується на електронних засобах відображення.

Розвиток інформаційних технологій та їх використання у військах (силах) викликає необхідність удосконалення спеціальних програмних засобів 3 обробки оперативнотактичної інформації для нанесення на цифрові карти місцевості [9]. Водночас не коректно стверджувати, що відбувається повна заміна паперових карт на цифрову інформацію про місцевість, йдеться лише про спільне їх використання та доповнення один одного. Паперові карти будуть необхідними у використанні протягом найближчого майбутнього (а іноді заміни їм немає), отже органи військового управління матимуть додаткові джерела просторової інформації для підтримки прийняття рішень.

Основне призначення ГІС - забезпечити органам управління військ (сил) усіх рівнів надійний та безперервний доступ до просторових даних.

ГІС $\epsilon$ основним джерелом геопросторової інформації (у вигляді ЦКІ) про місцевість та об'єкти на ній.

ГІС дає змогу створювати такі ЦМО, які відображають інформацію, яка точно відповідає потребам користувача. Крім того, ГІС надає нові можливості тривимірного відображення картографічної інформації, що недоступні для паперових карт. Тривимірне представлення ЦМО у конкретній точці місцевості дасть більш повну картину обстановки командувачу (командиру, начальнику) будь-якого рівня управління, ніж паперова карта.

Одна 3 головних вимог до карти командувача (командира, начальника) відображення змін оперативно-тактичної обстановки у часі. ГІС дає змогу відображати ЦМО у вигляді шарів, що перекриваються, висвітлювати поточну оперативно-тактичну обстановку на місцевості [9].

ГІС дає змогу швидко відобразити зміни обстановки, яка склалася завдяки передачі по каналах зв'язку відповідних шарів 3 інформацією. До того ж важливо передбачити швидкий друк обстановки на папері, зокрема на паперовій карті.

Отже, електронна карта виконуватиме свої функції лише тоді, коли вона буде забезпечена відповідним інструментарієм. Без засобів перегляду, нанесення умовних тактичних та інших знаків, аналізу, друку, які дають змогу реалізувати ЦМО, вона не відповідатиме необхідним вимогам.

ГІС військового призначення має забезпечувати вирішення таких основних завдань [10]:

формування ЦКІ про місцевість;

автоматизацію процесів створення, оновлення та підготовки до друку топографічних карт усього масштабного ряду; формування електронних карт різних масштабів;

накладання цифрових даних обстановки на відповідну цифрову картографічну основу; доведення до органів управління та військ (сил) ЦКІ про місцевість і об’єкти на ній, цифрових даних обстановки;

створення, розповсюдження i накопичення в електронному вигляді графічних документів на основі цифрових карт та можливість отримання їх паперових копій;

здійснення обміну документами і базами даних між ГІС та іншими підсистемами i елементами автоматизованих систем управління військами (силами);

забезпечення застосування військами (силами) навігаційних приладів загального та індивідуального користування, а також роботи приладів управління високоточними засобами ураження;

здійснення контролю за переміщенням мобільних об'єктів;

впровадження заходів захисту інформації від несанкціонованого доступу. 
У процесі свого функціонування ГІС військового призначення має забезпечувати виконання таких функцій:

можливість введення в бази даних ГІС інформації будь-якого типу, включаючи автоматичну векторизацію графічної інформації з паперових носіїв;

можливість працювати з геопросторовими даними в різних картографічних проєкціях та системах координат;

можливість роботи як з векторними, так i з растровими форматами картографічних даних; можливість огляду i аналізу окремих інформаційних шарів;

гнучкий експорт-імпорт інформаційних шарів у бази даних;

формування (оновлення) баз даних картографічних об'єктів та їх характеристик; автоматичне обчислення площини, підрахунки відстань між пунктами;

прив'язка об'єктів: введення координат, введення назви та характеристик, визначення ділянки карти, яка зображена на екрані монітора;

панорамування: графічне зображення необхідної ділянки карти, як у площинному вигляді, так і в 3D форматі на екрані монітора; розміщення на екрані монітора декількох шарів карти та первинних даних; виведення за запитом на монітор (друк) інформації про об'єкт; виведення результатів картографування на друк (принтер, плоттер); можливість створення користувачами власних картографічних документів (спеціальних карт); можливість генералізації картографічного зображення (збільшення/зменшення масштабу); конструювання графічних елементів за допомогою графічного редактора.

Зростання вимог до мобільності військ, збільшення просторових показників, зменшення термінів розгортання військ потребує нових способів застосування сил i засобів топогеодезичного забезпечення, основними 3 яких є:

підготовка ЦКІ, формування на іiі основі геопросторових баз даних, 3 доведенням їх до органів управління та військ для застосування в системах підтримки прийняття рішень;

оперативне виготовлення в польових умовах спеціальних карт і фотодокументів про місцевість 3 використанням мобільних геоінформаційних комплексів;

постійна взаємодія органів топографічної служби і військової розвідки для забезпечення створення необхідних документів з інформацією про місцевість у масштабі часу наближеному до реального.
На сьогодні стає зрозумілим, що подальше підвищення бойових можливостей військ (сил) неможливе без удосконалення інформаційного забезпечення (перш за все на основі забезпечення вихідними топогеодезичними даними) ЗС України, інших складових сил оборони (насамперед, на тактичному рівні).

Очевидно, що пошуку шляхів щодо удосконалення інформаційного забезпечення ЗС України має передувати глибокий аналіз організації топогеодезичного забезпечення збройних сил найбільш розвинених країн світу за досвідом воєнних конфліктів останніх років, стану функціонування системи інформаційного забезпечення у рамках не тільки Міністерства оборони України, але і всієї держави.

Основними аспектами цього аналізу має бути:

відповідність переліку та обсягу завдань із забезпечення 3С України, інших складових сил оборони достовірною інформацією про місцевість реальним фінансовим, матеріальним та інформаційним ресурсам держави;

система пріоритетів користувачів геопросторової інформації в державі; можливість швидко реагувати на завдання забезпечення військ (сил) ЗС України, інших складових сил оборони інформацією про місцевість у будь-якому районі;

наявність інформаційних джерел, адекватних вимогам до складу, якості i актуальності інформації про місцевість;

відповідність наявних методів i технологій можливостям забезпечити реальні потреби військ (сил) ЗС України, інших складових сил оборони вихідною топогеодезичною інформацією.

\section{Висновки}

1. Одним 3 напрямів подальшого удосконалення топогеодезичне забезпечення як невід'ємної складової інформаційного забезпечення державного управління у військовій сфері для своєчасного i якісного задоволення геопросторовими даними потреб ЗС України та інших складових сил оборони $є$ впровадження ГІС.

2. Стрімкий розвиток інформаційних технологій висуває нові вимоги до топогеодезичного забезпечення, зокрема:

повний перехід до цифрових технологій створення картографічної інформації;

можливість постійного використання геоінформаційних технологій для вирішення завдань аналізу місцевості та підтримки прийняття рішень;

забезпечення швидкого поширення геопросторової інформації до зацікавлених користувачів засобами автоматизованих систем управління. 
3. Досвід проведення АТО, ООС та останніх збройних конфліктів підтверджує, що у майбутньому потреба в картах, які надруковані на папері, збережеться, але виготовляти їх потрібно оперативно в безпосередній наближеності до району бойових дій, 3 використанням сучасних технологій друку на водостійкому папері для збільшення довговічності карт і зменшення їх витрат.

Перспектива подалыших досліджень полягає у пошуку шляхів удосконалення інформаційного забезпечення 3С України на підставі глибокого аналізу організації системи топогеодезичного забезпечення збройних сил найбільш розвинених країн світу за досвідом воєнних конфліктів останніх років, стану функціонування системи інформаційного забезпечення у рамках не тільки Міністерства оборони України, але і всієї держави 3 метою покладення його результатів в основу Концепції топогеодезичного та навігаційного забезпечення сектору безпеки і оборони держави.

\section{СПИСОК ВИКОРИСТАНОЇ ЛІТЕПАТУРИ}

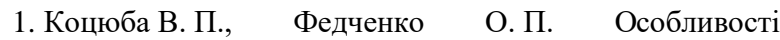
забезпечення збройних сил провідних країн світу вихідними топогеодезичними даними у збройних конфліктах останніх десятиліть. Харків : ХУПС ім. І. Кожедуба; Київ: НУОУ, 2010.

2. Стан та основні напрями розвитку топографогеодезичної і картографічної діяльності в Україні / О. Дишлик та ін. ; за заг. ред. Р. Сосси. Київ : НДІГК, 2006. С. 15-16. (Сер. Геодезія, картографія, кадастр).
3. Cocca P. I. Топографічне картографування України (1917-2012) : монографія. Київ : Наукова думка, 2014. $384 \mathrm{c}$.

4. Cocca Р., Голубінка Ю. Сучасні виклики до топогеодезичного та картографічного забезпечення. Львів, 2010

5. Про національну безпеку України : Закон України від 21.06.2018 p. № 2469-VIII.

6. Військовий стандарт ВСТ 01.004.004-2014 (01), Воєнна політика, безпека та стратегічне планування. Інформаційна безпека держави у воєнній сфері. Терміни та визначення.

7. Про затвердження Порядку загальнодержавного топографічного i тематичного картографування : Постанова Кабінету Міністрів України від 04.09.2013 p. № 661 .

8. Головльов Е. Ю., Фурманов К. В., Казмірчук Р. В. До питання вибору раціонального складу системи топогеодезичного і навігаційного забезпечення військ (сил) при впровадженні геоінформаційної системи у Збройних Силах України. Системи озброєння $i$ військова техніка. Військово-технічні проблеми. Київ, 2009. № 4 (20). C. 37-40.

9. Бобильов В. С. Застосування геоінформаційних технологій при плануванні та проведенні органами військового управління Збройних Сил України бойових дій та військових операцій : збірник тез доповідей IV Міжнародної науково-практичної конференції НУОУ (м. Київ, 10 квітня 2019 р.). Київ, 2019.

10. Брезіцький Е. Ю. Географічна інформаційна система військового призначення як складова частина інформаційного забезпечення процесу управління військами (силами) : збірник тез доповідей IV Міжнародної науково-практичної конференції НУОУ (м. Київ, 10 квітня 2019 р.). Київ, 2019.

Стаття надійшла до редакційної колегії 19.12.2019

Topographic and geodetic support as a component of information support for the defense forces of Ukraine

\section{Annotation}

The article is devoted to consideration of approaches to determination of priority directions of development of the system of topographic and geodetic support as a component of information support of the Armed Forces of Ukraine (Defense Forces). The main results of the analysis of the experience of conducting anti-terrorist operation, joint operation in the east of Ukraine and the participation of the armed forces of the leading states in the military conflicts of the last decades are presented. Based on the analysis, new requirements for topographic and geodetic support have been established, which puts forward the rapid development of information technologies in the world, in particular, full transition to digital technologies of mapping information creation, use of geo-information technologies for solving problems of terrain analysis and decision support, rapid provision of users with geospatial information for through automated control systems.

The basic concepts are structured: geoinformation support, digital mapping information, digital environment model, digital map, electronic map. The main tasks of the geographical information systems of the military purpose for enhancing the combat capabilities of the troops (forces) by improving the information support of the Armed Forces (Defense Forces) are determined. The necessity of development of information technologies and their introduction in the troops (forces), improvement of special software for processing of operational and tactical information for drawing on digital maps of terrain is substantiated. The main aspects of the analysis of the organization of topographic and geodetic support of the Armed Forces of the developed countries of the world, the state of functioning of the information support system of Ukraine to find ways to improve the information support of the Armed Forces.

The directions of further improvement of the topographic and geodetic support as an integral part of the information support of the state administration in the military sphere for timely and qualitative satisfaction of geospatial data the Armed Forces (Defense Forces) are widely considered through the widespread introduction of modern geographical information systems.

Keywords: topographic and geodetic support, geographic information system. 